Dapat diakses pada: http://jkb.ub.ac.id/index.php/jkb/article/view/1917

Jurnal Kedokteran Brawijaya Vol. 30, No. 1, Februari 2018, pp. 47-52

Article History: Received 13 Januari 2017, Accepted 8 September 2017

Artikel Penelitian

\title{
Prevalensi dan Pola Sensitivitas Enterobacteriaceae Penghasil ESBL di RSUD Arifin Achmad Pekanbaru
}

\section{Prevalence and Susceptibility Profile of ESBL-Producing Enterobacteriaceae in Arifin Achmad General Hospital Pekanbaru}

\author{
Dewi Anggraini ${ }^{1}$, Uswathun Hasanah $S^{1}$, Maya Savira ${ }^{1}$, Fauzia Andrini $D^{1}$, Dino Irawan ${ }^{2}$, Ruza Prima $R^{3}$ \\ ${ }^{1}$ KJF Mikrobiologi Fakultas Kedokteran Universitas Riau Pekanbaru \\ ${ }^{2}$ KJF Anestesi dan Terapi Intensif Fakultas Kedokteran Universitas Riau Pekanbaru \\ ${ }^{3}$ KJF Obstetri dan Ginekologi Fakultas Kedokteran Universitas Riau Pekanbaru
}

\begin{abstract}
ABSTRAK
Resistensi antibiotik merupakan masalah besar baik di rumah sakit maupun di masyarakat, resistensi menyebabkan pilihan terapi infeksi menjadi terbatas. Prevalensi resistensi antibiotik cenderung makin meningkat, salah satu diantaranya adalah bakteri ESBL (extended spectrum beta lactamases), suatu kelompok bakteri penghasil enzim yang dapat menghidrolisis antibiotik beta laktam yang mengandung grup oxyimino seperti sefalosporin generasi satu sampai ketiga dan aztreonam. Penelitian ini dilakukan secara deskriptif retrospektif yang bertujuan untuk mengetahui prevalensi ESBL pada Klebsiella pneumoniae dan Escherichia coli, serta pola sensitivitasnya di RSUD Arifin Achmad Pekanbaru. Data diambil dari hasil kultur bakteri dan uji resistensi antibiotik dari berbagai spesimen klinik yang diperiksa di Laboratorium Mikrobiologi RSUD Arifin Achmad selama tahun 2015. Uji ESBL dilakukan dengan alat VITEK 2 compact yang membandingkan antara proporsi penurunan pertumbuhan bakteri terhadap antibiotik sefalosporin saja dengan antibiotik kombinasi sefalosporin ditambah asam klavulanat. Hasil penelitian menunjukkan ESBL-K. pneumoniae sebesar $66,2 \%$, dan ESBL-E. coli 62,2\%, dan total rata-rata pada kedua bakteri 65,2\%. Prevalensi ESBL-K. pneumoniae dan ESBL-E. coli paling tinggi berasal dari ruangan Instalasi Perawatan Intensif Anak dan berasal dari spesimen sputum dan pus, namun secara statistik tidak didapatkan perbedaan bermakna proporsi ESBL positif dan negatif berdasarkan asal ruangan dan jenis spesimen. Sensitivitas ESBL-K. pneumoniae dan ESBL-E. coli paling baik dengan antibiotik golongan karbapenem, amikasin dan tigesiklin. Penelitian ini menunjukkan tingginya prevalensi $K$. pneumoniae dan E. coli penghasil ESBL di RSUD Arifin Achmad dibanding beberapa rumah sakit rujukan nasional dii Indonesia. Saran untuk menurunkan angka ESBL dengan cara mencegah transmisi melalui penerapan kewaspadaan kontak dan kewaspadaan berbasis transmisi, aspek pencegahan dan pengendalian infeksi dan peningkatkan rasionalisasi penggunaan antimikroba harus dilakukan.
\end{abstract}

Kata Kunci: ESBL, Escherichia coli, Klebsiella pneumonae, pola sensitivitas

\begin{abstract}
Antibiotic resistance is a major problem both in hospitals and in communities. Resistance causes limited infective therapeutic options. The prevalence of antibiotic resistance tends to increase, one of which is ESBL (extended spectrum beta lactamases) bacteria, a group of enzyme-producing bacteria that can hydrolyze beta lactam antibiotics containing oxyimino groups such as first to third generation cephalosporin and aztreonam. This retrospective descriptive research was conducted to know the prevalence of ESBL on Klebsiella pneumoniae and Escherichia coli, and its sensitivity pattern at Arifin Achmad General Hospital Pekanbaru. The data were collected from bacterial culture and antibiotic resistance test from various clinical specimens examined at Microbiology Laboratory of Arifin Achmad Hospital during 2015. ESBL test was done using VITEK 2 compact device that compared the proportion of decreasing bacterial growth to cephalosporin antibiotic alone with cephalosporin antibiotic combined with clavulanic acid. The results showed that ESBL-K. pneumoniae was $66,2 \%$ and ESBL-E. coli was $62.2 \%$, and the mean total of both bacteria was $65,2 \%$. The highest prevalence of ESBL-K. pneumoniae and ESBL-E. coli came from Intensive Care Nursing Room and came from sputum and pus specimens, but there was no statistically significant difference in the proportion of ESBL positive and negative based on the origin of the room and the specimen type. The sensitivity of ESBL-K. pneumoniae and ESBL-E. coli was best with carbapenem, amikacin, and thresicline antibiotics. This study shows the high prevalence of K. pneumoniae and E. coli producing ESBL in Arifin Achmad Hospital compared to some national referral hospitals in Indonesia. Suggestions for lowering ESBL numbers are by preventing transmission through the application of contact precautions and transmission-based precautions. Prevention and control of infection and improving rationalization of antimicrobial use should be undertaken.
\end{abstract}

Keywords: ESBL, Escherichia coli, Klebsiella pneumoniae, susceptibility profile

Korespondensi: Dewi Anggraini. Laboratorium Mikrobiologi Fakultas Kedokteran Universitas Riau Pekanbaru, Jl. Diponogoro No. 1 Pekanbaru, Riau Tel.081280104689Email: dewianggrainiyovi@gmail.com 


\section{PENDAHULUAN}

Penggunaan sefalosporin generasi ketiga di awal 1980-an dianggap sebagai suatu terobosan besar dalam melawan peningkatan prevalensi resistensi bakteri terhadap antibiotik yang dimediasi enzim beta laktamase (1). Paparan terus menerus dari antibiotik beta laktam dalam jumlah besar menginduksi produksi serta mutasi enzim beta laktamase pada bakteri-bakteri tersebut. Mutasi ini memperluas aktivitas enzim beta laktamase sehingga dapat menghidrolisis antibotik beta laktam yang baru dikembangkan. Enzim ini dikenal sebagai extended spectrum beta lactamases (ESBL) (2).

ESBL pertama kali ditemukan pada 1983, sejak saat itu bakteri Gram negatif yang memproduksi ESBL muncul sebagai ancaman besar bagi seluruh dunia. ESBL dapat menghidrolisis antibiotik beta laktam yang mengandung grup oxyimino seperti sefalosporin generasi ketiga dan aztreonam. Enzim ini dapat dihambat oleh penghambat beta laktamase seperti asam klavulanat, sulbaktam, dan tazobaktam. Gen pembawa ESBL seperti TEM-1, TEM-2, atau SHV-1 didapat dari mutasi yang mengubah konfigurasi asam amino di sekitar daerah yang aktif dari beta laktamase tersebut. ESBL yang bukan turunan TEM atau SHV telah banyak ditemukan belakangan ini (1). Jumlah varian ESBL terus meningkat mencapai 300 varian ESBL berbeda yang diketahui (3). ESBL biasanya dimediasi oleh plasmid. Enzim ini sering ditemukan pada Klebsiella pneumoniae, Escherichia coli dan basil Gram negatif lainnya (3). Bakteri yang memproduksi ESBL biasanya berhubungan dengan resistensi banyak obat lainnya seperti kuinolon dan aminoglikosida, karena gen yang terlibat pada mekanisme resistensi ini biasanya terletak pada plasmid yang sama dengan gen ESBL (1).

Saat ini telah banyak dilaporkan wabah Enterobacteriaceae yang memproduksi ESBL di unit perawatan intensif dan neonatus yang berhubungan dengan peningkatan angka morbiditas dan mortalitas (1). Dalam upaya untuk mencegah timbulnya dan meluasnya bakteri resisten di rumah sakit, penting untuk mewaspadai organisme yang memproduksi ESBL, salah satunya dengan mengetahui prevalensi ESBL pada Escherichia coli dan Klebisella penumoniae.

\section{METODE}

\section{Desain Penelitian}

Penelitian ini merupakan penelitian deskriptif retrospektif. Data diambil dari hasil pemeriksaan kultur dan uji resistensi yang dikerjakan di Bagian Mikrobiologi Laboratorium Patologi Klinik RSUD Arifin Achmad. Populasi adalah seluruh data hasil kultur bakteri dan uji resistensi antibiotik dari berbagai spesimen klinik pasien RSUD Arifin Achmad periode 1 Januari 2015-31 Desember 2015. Kriteria eksklusi yaitu data yang tidak lengkap yang meliputi jenis bakteri, hasil uji ESBL dan hasil uji resistensi antibiotik, asal ruangan, jenis spesimen.

\section{Uji ESBL dan Uji Resistensi Antibiotik}

Prosedur pemeriksaan dimulai dengan penanaman spesimen klinik di medium yang sesuai, dengan inkubasi di lingkungan yang sesuai. Identifikasi $K$. pneumoniae dan E. coli dilakukan dengan melihat morfologi koloni, pewarnaan Gram dan dilanjutkan dengan alat VITEK 2 compact dengan menggunakan kartu GN. Uji ESBL untuk bakteri $K$. pneumoniae dan $E$. coli dilakukan dengan alat VITEK 2 compact, menggunakan kartu AST-GN93. Kartu ini memiliki 6 sumur yang berisi sefepim dengan konsentrasi $1,0 \mu \mathrm{g} / \mathrm{ml}$, seftriakson $0,5 \mu \mathrm{g} / \mathrm{ml}$, seftazidim $0,5 \mu \mathrm{g} / \mathrm{ml}$, kombinasi sefepim/asam klavulanat $1,0 / 10 \mu \mathrm{g} / \mathrm{ml}$, seftriakson/asam klavulanat $0,5 / 4 \mu \mathrm{g} / \mathrm{ml}$, seftazidim/asam klavulanat $0,5 / 4 \mu \mathrm{g} / \mathrm{ml}$. Pertumbuhan bakteri di masing-masing sumur dinilai secara kuantitatif dengan pelacak optikal. Proporsi penurunan pertumbuhan bakteri dengan adanya sefalosporin saja dibandingkan dengan kombinasi sefalosporin dengan asam klavulanat menunjukkan produksi ESBL. Identifikasi dan uji resistensi antibiotik $K$. pneumoniae dan E. coli juga dilakukan dengan menggunakan alat VITEK 2 compact. Jenis antibiotik yang diujikan adalah ampisilin, ampisilin/sulbaktam, piperasilin/tazobactam, sefazolin, seftriakson, seftazidim, sefepim, aztreonam, meropenem, ertapenem, gentamisin, amikasin, ciprofloksasin, tigesiklin, trimetroprim/sulfametoksazol, dan nitrofurantoin.

\section{Pengumpulan dan Pengolahan Data}

Pengumpulan data pemeriksaan kultur dan uji resistensi didapat dari buku register. Hasil kultur bakteri dan uji resistensi antibiotik dicetak dari alat VITEK 2 compact, sesuai dengan yang tertera dalam buku registrasi, kemudian dilakukan pemeriksaan kembali kelengkapan data. Data-data jenis bakteri, hasil uji ESBL dan hasil uji resistensi antibiotik, asal ruangan, jenis spesimen. dimasukkan ke dalam perangkat lunak WHONET 5.6. Pengolahan data termasuk pola sensitivitas antimikroba dilakukan dengan WHONET 5.6. Untuk menilai perbedaan hasil identifikasi bakteri berdasarkan lokasi dan asal spesimen digunakan uji statistik koefisien kontingensi, dikatakan bermakna bila nilai $p<0,05$. Penelitian ini telah Iolos kaji etik dari Unit Etika Penelitian Fakultas Kedokteran dan Kesehatan Fakultas Kedokteran Universitas Riau dengan nomor 202/UN.19.5.1.1.8/UEPKK/2016.

\section{HASIL}

Sepanjang tahun 2015 diisolasi 1.121 bakteri, dengan jumlah isolat K.pneumoniae adalah 228 (20,3\%) dan E.coli 82 isolat $(7,3 \%)$, masing-masing menempati urutan kedua dan keempat tersering bakteri yang diisolasi. Prevalensi ESBL positif pada $K$. pneumoniae adalah $66,2 \%$ sedangkan pada $E$. coli adalah $62,2 \%$, atau total pada kedua bakteri tersebut adalah $65,2 \%$ (tabel 1 ).

Tabel 1. Prevalensi ESBL positif dan negatif pada $K$. pneumoniae dan E.coli

\begin{tabular}{lcccccc}
\hline \multirow{2}{*}{ Bakteri } & \multicolumn{2}{c}{$\boldsymbol{K}$. pneumoniae } & \multicolumn{2}{c}{ E.coli } & \multicolumn{2}{c}{ Total } \\
\cline { 2 - 7 } & $\mathbf{n}$ & $\boldsymbol{\%}$ & $\mathbf{n}$ & $\%$ & $\mathbf{n}$ & $\%$ \\
\hline ESBL positif & 151 & $66,2 \%$ & 51 & $62,2 \%$ & 202 & $65,2 \%$ \\
ESBL negatif & 77 & $33,8 \%$ & 31 & $37,8 \%$ & 108 & $34,8 \%$ \\
& 228 & $100,0 \%$ & 82 & $100 \%$ & 310 & $100 \%$ \\
\hline
\end{tabular}

Prevalensi K. pneumoniae dan E. coli ESBL positif berdasarkan asal ruangan dapat dilihat pada Tabel 2. $K$. pneumoniae ESBL positif lebih sering ditemukan dibandingkan $K$. pneumoniae ESBL negatif di seluruh ruangan kecuali di poliklinik. E. coli ESBL positif lebih sering 
Tabel 2. Prevalensi K.pneumoniae dan E. coli ESBL positif berdasarkan asal ruangan

\begin{tabular}{|c|c|c|c|c|c|c|}
\hline \multirow{2}{*}{ Ruangan } & \multicolumn{3}{|c|}{ K. pneumoniae } & \multicolumn{3}{|c|}{ E. coli } \\
\hline & ESBL positif & Total & Prevalensi & ESBL positif & Total & Prevalensi \\
\hline Instalasi Perawatan Intensif dewasa & 31 & 58 & $53,4 \%$ & 6 & 8 & $75,0 \%$ \\
\hline Instalasi Perawatan Neonatus & 12 & 16 & $75,0 \%$ & 1 & 4 & $25,0 \%$ \\
\hline Instalasi Perawatan Intensif Anak & 14 & 17 & $82,4 \%$ & 1 & 1 & $100,0 \%$ \\
\hline IRNA Medikal & 36 & 50 & $72,0 \%$ & 13 & 25 & $52,0 \%$ \\
\hline IRNA Surgikal & 37 & 59 & $62,7 \%$ & 20 & 27 & $74,1 \%$ \\
\hline VIP & 15 & 19 & $78,9 \%$ & 5 & 9 & $55,6 \%$ \\
\hline Instalasi Fetomaternal & 4 & 5 & $80,0 \%$ & 2 & 3 & $66,7 \%$ \\
\hline Poliklinik & 2 & 4 & $50,0 \%$ & 3 & 5 & $60,0 \%$ \\
\hline Total & 151 & 228 & $66,2 \%$ & 51 & 82 & $62,2 \%$ \\
\hline
\end{tabular}

ditemukan di hampir seluruh ruangan kecuali Instalasi Perawatan Neonatus. ESBL positif paling tinggi prevalensinya di Instalasi Perawatan Intensif Anak, yaitu $82,4 \%$ untuk K. pneumoniae dan $100 \%$ untuk E. coli. Jika dilihat dari distribusinya $K$. pneumoniae dan E. coli ESBL positif paling banyak berasal dari IRNA Surgikal yaitu masing-masing 24,5\% dan 39,2\%) (Tabel 3). Berdasarkan uji statistik tidak ada perbedaan bermakna proporsi ESBL berdasarkan asal ruangan pada K. pneumoniae dan E. coli (masing-masing $p=0,183 ; p=0,488$ ).

Tabel 3. Distribusi Frekuensi K. pneumoniae dan E. coli ESBL positif berdasarkan asal ruangan

\begin{tabular}{lrrrr}
\hline \multirow{2}{*}{ Ruangan } & \multicolumn{2}{c}{$\begin{array}{c}\text { K. peumonia ESBL } \\
\text { positif }\end{array}$} & $\begin{array}{c}\text { E. coli ESBL } \\
\text { positif }\end{array}$ \\
\cline { 2 - 5 } & $\mathbf{n}$ & Persentase & $\mathbf{n}$ & Persentase \\
\hline $\begin{array}{l}\text { Instalasi Perawatan Intensif } \\
\text { dewasa }\end{array}$ & 31 & $20,5 \%$ & 6 & $11,8 \%$ \\
Instalasi Perawatan & 12 & $7,9 \%$ & 1 & $1,9 \%$ \\
$\begin{array}{l}\text { Neonatus } \\
\text { Instalasi Perawatan Intensif }\end{array}$ & 14 & $9,3 \%$ & 1 & $1,9 \%$ \\
$\begin{array}{l}\text { Anak } \\
\text { IRNA Medikal }\end{array}$ & 36 & $23,8 \%$ & 13 & $25,4 \%$ \\
IRNA Surgikal & 37 & $24,5 \%$ & 20 & $39,2 \%$ \\
VIP & 15 & $9,9 \%$ & 5 & 9,8 \\
Instalasi Fetomaternal & 4 & $2,6 \%$ & 2 & $3,9 \%$ \\
Poliklinik & 2 & $1,3 \%$ & 3 & $5,9 \%$ \\
Total & 151 & $100 \%$ & 51 & $100 \%$ \\
\hline
\end{tabular}

Prevalensi $K$. pneumoniae dan E. coli ESBL positif dan negatif berdasarkan jenis spesimen dapat dilihat pada Tabel 4. K. pneumoniae ESBL positif lebih sering ditemukan pada semua spesimen dibandingkan $K$. pneumoniae ESBL negatif, kecuali yang berasal dari spesimen urin persentase $K$. pneumoniae ESBL positif sama dengan ESBL negatif. E. coli ESBL positif lebih sering dari semua spesimen kecuali darah. ESBL positif paling tinggi prevalensinya pada spesimen sputum (untuk $K$. pneumoniae $69,5 \%$ ) dan pus (untuk E. coli 73,3\%). Jika dilihat dari distribusinya $K$. pneumoniae ESBL positif paling banyak berasal dari sputum $(43,7 \%)$, dan E. coli ESBL positif paling banyak berasal dari pus (64,7\%) (Tabel 5). Berdasarkan uji statistik tidak ada perbedaan bermakna proporsi ESBL berdasarkan jenis spesimen pada $K$. pneumoniae dan $E$. coli (masing-masing $p=0,746$; $p=0,126)$.
Tabel 4. Prevalensi K. pneumoniae dan E. coli ESBL positif dan ESBL negatif berdasarkan jenis spesimen

\begin{tabular}{lrrrrrr}
\hline \multirow{2}{*}{$\begin{array}{l}\text { Jenis } \\
\text { Spesimen }\end{array}$} & $\begin{array}{c}\text { ESBL } \\
\text { positif }\end{array}$ & Total & Prevalensi & $\begin{array}{c}\text { ESBL } \\
\text { positif }\end{array}$ & Total Prevalensi \\
\hline Sputum & 66 & 95 & $69,5 \%$ & 33 & 13 & $61,5 \%$ \\
Pus & 56 & 83 & $67,5 \%$ & 8 & 45 & $73,3 \%$ \\
Darah & 13 & 21 & $61,9 \%$ & 5 & 12 & $41,7 \%$ \\
Urin & 8 & 16 & $50,0 \%$ & 1 & 5 & $20,0 \%$ \\
Lain & 8 & 13 & $61,5 \%$ & 8 & 13 & $61,5 \%$ \\
Total & 151 & 228 & $66,2 \%$ & 51 & 82 & $62,2 \%$ \\
\hline
\end{tabular}

Tabel 5. Distribusi $K$. pneumoniae dan E. coli ESBL positif berdasarkan spesimen

\begin{tabular}{lcccc}
\hline \multirow{2}{*}{ Jenis Spesimen } & \multicolumn{2}{c}{$\begin{array}{c}\text { K. pneumonia } \text { ESBL } \\
\text { positif }\end{array}$} & \multicolumn{2}{c}{ E. coliESBL positif } \\
\cline { 2 - 5 } & ESBL positif & Persentase & ESBL positif & Persentase \\
\hline Sputum & 66 & $43,7 \%$ & 8 & $15,7 \%$ \\
Pus & 56 & $37,1 \%$ & 33 & $64,7 \%$ \\
Darah & 13 & $8,6 \%$ & 5 & $9,8 \%$ \\
Urin & 8 & $5,3 \%$ & 1 & $2,0 \%$ \\
Lain & 8 & $5,3 \%$ & 8 & $15,7 \%$ \\
Total & 151 & $100 \%$ & 51 & $100 \%$ \\
\hline
\end{tabular}

Tabel 6. Pola sensitifitas antimikoba K. pneumoniae dan E. coli ESBL positif

\begin{tabular}{lrr}
\hline Antibiotik & $\begin{array}{c}\boldsymbol{K} \text {. pneumoniae ESBL } \\
\text { positif }\end{array}$ & $\begin{array}{c}\text { E. coliESBL } \\
\text { positif }\end{array}$ \\
\hline ampisilin & $0 \%$ & $0 \%$ \\
ampisilin/sulbaktam & $7,3 \%$ & $27,5 \%$ \\
piperasilin/tazobactam & $40,0 \%$ & $49,0 \%$ \\
sefazolin & $0 \%$ & $0 \%$ \\
seftriakson & $0 \%$ & $0 \%$ \\
seftazidim & $0 \%$ & $0 \%$ \\
sefepim & $0 \%$ & $2,0 \%$ \\
aztreonam & $0 \%$ & $2,0 \%$ \\
meropenem & $94,0 \%$ & $98,0 \%$ \\
ertapenem & $93,4 \%$ & $98,0 \%$ \\
gentamisin & $35,1 \%$ & $56,9 \%$ \\
amikasin & $96,7 \%$ & $100 \%$ \\
ciprofloksasin & $32,5 \%$ & $13,7 \%$ \\
tigesiklin & $76,8 \%$ & $100 \%$ \\
trimetroprim/sulfametoksazol & $25,2 \%$ & $29,4 \%$ \\
nitrofurantoin & $16,5 \%$ & $62,8 \%$ \\
\hline
\end{tabular}


Pola sensitivitas antimikroba K. pneumoniae dan E. coli ESBL positif dapat dilihat pada Tabel 6 . Sensitifitas $K$. pneumoniae ESBL positif paling baik dengan amikasin $(96,7 \%)$, meropenem dan ertapenem masing-masing $94,0 \%$ dan $93,4 \%$, serta tigesiklin (76,8\%). Sensitivitas $E$. coli ESBL positif paling baik dengan amikasin dan tigesiklin masing-masing $100 \%$, serta meropenem dan ertapenem masing-masing 98\%. Sensitivitas K. pneumoniae dan $E$. coli ESBL positif terhadap antibiotik golongan lain berada di bawah $50 \%$, seperti terhadap ciprofloksasin, ampisilin/sulbaktam, piperasilin/tazobactam, trimetroprim/sulfametoksazol, dan nitrofurantoin. Sensitivitas $K$. pneumoniae dan E. coli ESBL positif terhadap ampisilin, sefalosporin generasi pertama (sefazolin), ketiga (seftriakson dan seftazidim), keempat (sefepim) serta aztreonam berkisar $0 \%$. Pada penelitian ini ditemukan 9 dari 151 (6\%) K. pneumoniae ESBL positif, dan 1 dari 51 (2\%) E. coli ESBL positif juga resisten dengan meropenem (carbapenem resistant Enterobacteriaceae).

\section{DISKUSI}

Pada penelitian ini didapatkan prevalensi ESBL positif pada $K$. pneumoniae adalah $66,2 \%$ sedangkan pada $E$. coli adalah $62,2 \%$, dan total pada kedua bakteri $65,2 \%$. Hasil ini lebih tinggi dibandingkan data Surveilans Program Pengendalian Resistensi Antimikroba RSDS-BalitbangkesWHO tahun 2013, prevalensi ESBL di beberapa rumah sakit rujukan nasional di Indonesia berkisar dari 32,1\% sampai $56,8 \%$ untuk $K$. pneumoniae, dan $26,7 \%$ sampai $56,8 \%$ untuk E. coli (4).

Prevalensi ESBL di India berkisar antara 17\% sampai 73,5\% untuk K. pneumoniae dan $13,5 \%$ sampai $73,5 \%$ untuk $E$. coli (5). Dilaporkan ESBL yang tinggi pada semua strain bakteri Gram negatif di India Utara dan Selatan (6), dan penelitian yang dilakukan pada 10 pusat kesehatan lainnya di negara ini menunjukkan bahwa angka Enterobacteriaceae yang memproduksi ESBL mencapai angka $70 \%$ (7). Produksi ESBL diamati pada $48 \%$ E. coli, 44\% K. pneumoniae dan $50 \%$ P. aeruginosa yang diisolasi pada rumah sakit tersier di Patiala, Punjab (8). Pada penelitian lainnya, didapatkan angka ESBL adalah $46 \%$ dan $50 \%$ pada pasien rawat jalan dan rawat inap secara berurutan (9) dan Nasa dkk. mendeteksi produksi ESBL pada hampir $80 \%$ isolat klinis (10). Berdasarkan program surveilans SENTRY terdapat peningkatan pesat $K$. pneumoniae yang memproduksi ESBL (hingga 60\%) dan $E$. coli (13-35\%) di daerah-daerah yang berbeda di Cina (11). Prevalensi Enterobacteriaceae yang memproduksi ESBL di negara-negara Timur Tengah juga mengkhawatirkan, wilayah ini mungkin merupakan salah satu pusat dari pandemis global ESBL. Investigasi yang dilakukan di negara tersebut menunjukkan $61 \%$ dari $E$. coli memproduksi ESBL (12).

Berdasarkan data dari European Antimicrobial Resistance Surveillance System (EARSS), 2,6\% kelompok E. coli dan $1,7 \%$ kelompok $K$. pneumoniae di Swedia resisten terhadap sefalosporin generasi ketiga pada 2010 (13). Pada survei tahun 1997-1998 di Eropa, 74\% Klebsiella memproduksi ESBL (1). Sebuah investigasi yang dilakukan pada tahun 2009 menunjukkan $9 \%$ isolat $E$. coli di pusat kanker di Texas merupakan penghasil ESBL (14). Sanchez et al., menginvestigasi data yang diperoleh dari The Surveillance Network (TSN) yang mencakup resistensi antimikroba in vitro pada pasien rawat jalan di Amerika Serikat antara tahun 2000 sampai 2010, dan hasilnya menunjukkan resistensi terhadap seftriakson meningkat dari $0,2 \%$ menjadi $2,3 \%$ dan resistensi terhadap sefuroksim meningkat dari $1,5 \%$ menjadi $5 \%$, namun isolat bakteri yang difokuskan tidak diperiksa ESBL-nya (15). Laporan lainnya dari Molan dkk., menunjukkan isolat yang yang memproduksi ESBL ditemukan pada $75 \%$ dari 24 pusat kesehatan di Amerika Serikat (16) sedangkan di penelitian lainnya di sekitar Amerika Serikat, 44\% Klebsiella spp. ditemukan memproduksi ESBL $(16,17)$. Data-data di atas menunjukkan ESBL memiliki prevalensi yang tinggi di dunia dan tampaknya terus meningkat seiring berjalannya waktu, dan bervariasi di berbagai daerah.

Pada penelitian ini prevalensi ESBL positif paling tinggi didapatkan di ruangan Instalasi Perawatan Intensif Anak. Berdasarkan uji statistik tidak didapatkan perbedaan bermakna proporsi ESBL positif dan negatif berdasarkan asal ruangan baik pada $K$. pneumoniae maupun E. coli. Salah satu faktor risiko infeksi oleh organism penghasil ESBL adalah rawatan ICU, selain itu penggunaan antibiotik jangka panjang, prosedur invasif, dekubitus dan pemakaian kateter urin jangka lama juga dapat menjadi faktor risiko (18).

Pada penelitian ini prevalensi ESBL positif paling tinggi berasal dari spesimen sputum (untuk $K$. pneumoniae) dan pus (untuk E. coli). Berdasarkan uji statistik tidak didapatkan perbedaan bermakna proporsi ESBL positif dan negatif berdasarkan jenis spesimen baik pada $K$. pneumoniae maupun $E$. coli. Di beberapa penelitian lain prevalensi ESBL paling tinggi berasal dari spesimen urin dan pus $(18,19)$. Hal ini kemungkinan disebabkan karena secara umum di laboratorium kami asal sampel terbanyak adalah dari sputum dan pus.

Karbapenem merupakan pilihan pertama terapi infeksi serius yang disebakan oleh ESBL. Banyak penelitian melaporkan $>98 \%$ K. pneumoniae dan E. coli penghasil ESBL masih sensitif dengan karbapenem (2). Hasil ini sesuai dengan penelitian ini, sensitifitas $K$. pneumoniae ESBL positif untuk meropenem dan ertapenem masing-masing 94,0\% dan 93,4\% sedangkan untuk $E$. coli ESBL positif masing-masing masing-masing $98 \%$. Pada penelitian ini ditemukan (6\%) K. pneumoniae ESBL positif, dan $2 \%$ E. coli ESBL positif juga resisten dengan meropenem (carbapenem resistant Enterobacteriaceae). Penelitian di RS. Cipto Mangunkusumo Jakarta mendapatkan 25,89\% isolate Enterobacteriaceae yang resisten dengan sefalosporin generasi ketiga dan aztreonam juga resisten dengan karbapenem (19). Pilihan terapi lain untuk bakteri penghasil ESBL adalah fosfomisin, kolistin dan tigesiklin (2). Pada penelitian ini sensitifitas tigesiklin terhadap $K$. pneumoniae tidak sebaik karbapenem yaitu $76,8 \%$ dan terhadap E. coli sangat baik yaitu $100 \%$.

Bakteri yang memproduksi ESBL biasanya berhubungan dengan resistensi banyak obat lainnya seperti kuinolon, aminoglikosida, karena gen yang terlibat pada mekanisme resistensi ini biasanya terletak pada plasmid yang sama dengan gen $\operatorname{ESBL}(5,6) \mathrm{Hal}$ ini sesuai dengan yang didapatkan pada penelitian ini sensitifitas $K$. pneumoniae dan E. coli ESBL positif terhadap antibiotik golongan lain berada di bawah $50 \%$, seperti terhadap ciprofloksasin, ampisilin/sulbaktam, piperasilin/tazobactam, trimetroprim/sulfametoksazol, dan nitrofurantoin.

Secara garis besar terdapat dua cara deteksi ESBL, yaitu deteksi fenotipik dan genotipik (20). Pada penelitian ini uji 
ESBL dilakukan dengan menggunakan alat VITEK 2 compact. Alat ini mendeteksi produksi ESBL berdasarkan penilaian yang simultan terhadap daya hambat sefepim, seftazidim dan seftriakson dengan atau tanpa asam klavulanat, sesuai dengan standar deteksi fenotipik ESBL dari The Clinical and Laboratory Standarts Institute (21). Berdasarkan penelitian Spanu dkk, yang mengevaluasi metode ini dibandingkan dengan metode genotipik sebagai baku emas, alat VITEK 2 compact merupakan metode yang cepat dan dapat dipercaya untuk identifikasi

\section{DAFTAR PUSTAKA}

1. Paterson D and Bonomo RA. Extended-Spectrum BLactamase: A Clinical Update. Clinical Microbiology Reviews. 2015; 18(4): 657-686.

2. Shaikh J, Fatima J, Shakil S, Rizvi S, and Kamal M. Antibiotic Resistance and Extended Spectrum BetaLactamase: Types, Epidemiology, and Treatment. Saudi Journal of Biological Sciences. 2015; 22(1): 90101.

3. Goyal A, Prasad KN, Prasad A, Gupta S, Ghoshal U, and Ayyagari A. Extended Spectrum B-Lactamases in Escherichia coli \& Klebsiella pneumoniae \& Associated Risk Factors. Indian Journal of Medical Research. 2009; 129(6): 695-700.

4. Komite Pengendalian Resistensi Antimikroba KEMENKES RI. AMR Masalah Nasional dan Global. Proceeding Workshop PPRA. Semarang, Maret 1316, 2016.

5. Bindu $\mathrm{MH}$, Kasturi $\mathrm{T}$, Reddy $\mathrm{CM}$ and Indu K. Prevalence of ESBL Production in Eschericia coli and Klebsiella spp from Different Clinical Samples-A Study in a Teaching Hospital in Telangana, India. International Journal of Current Microbiology and Applied Sciences. 2015; 4(3): 236-243.

6. Khurana S, Mathur P, Kapil A, Valsan C, and Behera B. Molecular Epidemiology of Beta-lactamase producing Nosocomial Gram-negative Pathogens frmo North and South Indian Hospitals. Journal Medical Microbiology. 2017; 66(7): 999-1004.

7. Rupinder B, Geeta W, and Shikha J. Prevalence of Extended Spectrum b-Lactamases in Multidrug Resistant Strains of Gram negative Bacilli. Journal of Academia Industrial Research. 2013; 1(9): 558-560.

8. Sankar S, Narayanan H, Kuppanan $S$, and Nandagopal B. Frequency of Extended Spectrum Beta-Lactamase (ESBL) Producing Gram Negative Bacilli in a 200-Bed Multi-Specialty Hospital in Vellore District, Tamil Nadu, India. Infection. 2012; 40(4): 425-429.

9. Nasa P, Juneja D, Singh O, Dang R, and Singh A. An Observational Study on Bloodstream ExtendedSpectrum Beta-Lactamase Infection in Intensive Care Unit: Incidence, Risk Factors and Its Impact on Outcome. European Journal of Internal Medicine. 2012; 23(2): 192-195.

10. Hawkey P. Prevalence and Clonality of ExtendedSpectrum Beta-Lactamases in Asia. Clinical Microbiology and Infection. 2008; 14(1): 159-165.

11. Al-Agamy MMH, Ashour EMS, and Wiegand I. First rutin Enterobacteriaceae penghasil ESBL, dengan sensitifitas dan spesifisitas, nilai duga positif dan nilai duga negatif di atas $98 \%$ (22).

\section{UCAPAN TERIMA KASIH}

Terimakasih dan penghargaan kami sampaikan kepada pimpinan Fakultas Kedokteran Universitas Riau, manajemen RSUD Arifin Achmad dan semua pihak yang terlibat dalam proses penelitian.

Description of CTXM Beta-Lactamase-Producing Clinical Escherichia coli Isolates from Egypt. International Journal of Antimicrobial Agents. 2006; 27(6): 545-548.

12. The European Centre for Disease Prevention and Control. Antimicrobial Resistenace Surveillance in Europe 2012 . (OnIine) 2013 . https://ecdc.europa.eu/en/publicationsdata/antimicrobial-resistance-surveillance-europe2012. [diakses tanggal 20 September 2016].

13. Bhusal Y, Mihu CN, Tarrand JJ, and Rolston KV. Incidence of Fluoroquinolone-Resistant and ExtendedSpectrum Beta-Lactamse-Producing Escherichia coli at a Comprehensive Cancer Center in the United States. Chemotherapy. 2011; 57(4): 335-338.

14. Sanchez GV, Master RN, Karlowsky JA and Bordon JM. In Vitro Antimicrobial Resistance of Urinary Escherichia coli Isolates among US Outpatients from 2000 to 2010. Antimicrobial Agents and Chemotherapy. 2012; 56(4): 2181-2183.

15. Moland ES, Black JA, Ourada J, Reisbig MD, Hanson ND, and Thomson KS. Occurence of Newer BetaLactamases in Klebsiella pneumoniae Isolates from 24 US Hospitals. Antimicrobial Agents and Chemotherapy. 2002; 46(12): 3837-3842.

16. Saurina G, Quale JM, Manikal VM, Oydna E, and Landman D. Antimicrobial Resistance in Enterobacteriaceae in Brooklyn, NY: Epidemiology and Relation to Antibiotic Usage Patterns. Journal of Antimicrobial Chemotherapy. 2000; 45(6): 895-898.

17. Mathai D, Lewis MT, Kugler KC, Pfaller MA, Jones RN, and SENTRY Participants Group (North America). Antibacterial activity of 41 Antimicrobials Tested Against Over 2773 Bacterial Isolates From Hospitalized Patients with Pneumonia: I-Results From SENTRY Antimicrobial Surveillance Program (North America, 1998). Diagnostic Microbiology and Infectious Disease. 2001; 39(2): 105-116.

18. Singh N, Pattnaik D, Neogi D, Jenit J, and Mallick B. Prevalence of ESBL in Eschericia coli Isolates Among ICU Patients in a Tertiary Care Hospital. Journal of Clinical and Diagnostic Research. 2016; 10(9): 19-22.

19. Saharman $Y$ and Lestari D. Phenotype Characterization of Beta-Lactamase Producing Enterobacteriaceae in the Intensive Care Unit (ICU) of Cipto Mangunkusumo Hospital in 2011. Acta Medica Indonesiana. 2013; 45(1): 11-16.

20. Al-Bayssari C, Dabboussi F, Hamze $M$ and Rolain JM. Detection of Expanded-Spectrum B-Lactamses in Gram-Negative Bacteria in the 21st Century. Expert 
Review of Anti-Infective Therapy. 2015; 13(9): 11391158.

21. Clinical Laboratory Standard Institute. Performance Standards for Antimicrobial Susceptibility Testing. 26th edition. USA: Clinical Laboratory Standard Institute; 2017.
22. Spanu T, Sanguinetti $M$, Tumbarello $M$, et al. Evaluation of the New VITEK 2 Extended-Spectrum Beta-Lactamase (ESBL) Test for Rapid Detection of ESBL Production in Enterobacteriaceae Isolates. Journal of Clinical Microbiology. 2006; 44(9): 32573262. 